\title{
Application of H-Point Standard Addition Method and Multivariate Calibration Methods to the Simultaneous Kinetic-Potentiometric Determination of Cerium(IV) and Dichoromate
}

\author{
Mohammad Ali Karimi ${ }^{1,2 *}$, Mohammad Hossein Mashhadizadeh ${ }^{3}$, \\ Mohammad Mazloum-Ardakani ${ }^{4}$, Fatemeh Rahavian ${ }^{2}$ \\ ${ }^{1}$ Department of Chemistry \& Nanoscience and Nanotechnology Research Laboratory (NNRL), \\ Faculty of Sciences, Payame Noor University (PNU), Sirjan, Iran \\ ${ }^{2}$ Department of Chemistry, Faculty of Sciences, Payame Noor University (PNU), Ardakan, Iran \\ ${ }^{3}$ Department of Chemistry, Tarbiat Moallem University of Tehran, Tehran, Iran \\ ${ }^{4}$ Department of Chemistry, Faculty of Sciences, Yazd University, Yazd, Iran \\ E-mail:ma_karimi43@yahoo.com \& m_karimi@pnu.ac.ir \\ Received June 27, 2010; revised July 20, 2010; accepted July 26, 2010
}

\begin{abstract}
A kinetic-potentiometric method for simultaneous determination of Cerium(IV) and dichoromate $\left(\mathrm{Cr}_{2} \mathrm{O}_{7}^{2-}\right)$ by H-point standard addition method (HPSAM), partial least squares (PLS) and principal component regression (PCR) using fluoride ion-selective electrode (FISE) is described. In this work, the difference between the rate of the oxidation reaction of $\mathrm{Fe}(\mathrm{II})$ to $\mathrm{Fe}(\mathrm{III})$ in the presence of $\mathrm{Ce}^{4+}$ and $\mathrm{Cr}_{2} \mathrm{O}_{7}{ }^{2-}$ is based of the method. The rate of consume fluoride ion for making complex is detected with a FISE. The results show that simultaneous determination of $\mathrm{Ce}^{4+}$ and $\mathrm{Cr}_{2} \mathrm{O}_{7}{ }^{2-}$ can be done in their concentration ranges of 1.0-30.0 and $0.1-20.0 \mu \mathrm{g} / \mathrm{mL}$, respectively. The total relative standard error for applying the PLS and PCR methods on 8 synthetic samples was 2.97 and 3.19 , respectively in the concentration ranges of $1.0-30.0 \mu \mathrm{g} / \mathrm{mL}$ of Ce $\mathrm{Ce}^{4+}$ and $0.1-20.0 \mu \mathrm{g} / \mathrm{mL}$ of $\mathrm{Cr}_{2} \mathrm{O}_{7}{ }^{2-}$. In order for the selectivity of the method to be assessed, we evaluated the effects of certain foreign ions upon the reaction rate and assessed the selectivity of the method. The proposed methods (HPSAM, PLS and PCR) were evaluated using a set of synthetic sample mixtures and then applied for simultaneous determination of $\mathrm{Ce}^{4+}$ and $\mathrm{Cr}_{2} \mathrm{O}_{7}{ }^{2-}$ in different water samples.
\end{abstract}

Keywords: Multivariate Calibration, HPSAM, Simultaneous Kintic-Potentiometry, Dichromate, Cerium(IV)

\section{Introduction}

Dichromate $\left(\mathrm{Cr}_{2} \mathrm{O}_{7}^{2-}\right)$ and cerium(IV) are strong oxidants in chemistry that are used widely as oxidizing agent in diverse chemical reactions in the laboratory and industry for the synthesis of many different kinds of chemical compounds. Dichromate is used as a common inorganic chemical reagent, most commonly used as an oxidising agent in various laboratory and industrial applications $[1,2]$. It also used to oxidize alcohols, determination ethanol, cleaning laboratory glassware of organic contaminants [3]. Cerium(IV) is also a common inorganic chemical reagent and industrially important and is used in nuclear reactors, alloys with nickel and chromium, microwave devices, lasers, agriculture and miscellaneous [4-6]. In analytical chemistry, standardized aqueous solutions of $\mathrm{Cr}_{2} \mathrm{O}_{7}^{2-}$ and $\mathrm{Ce}^{4+}$ are sometimes used as oxidizing titrants for redox titrations. Therefore, determination of these oxidants is very important. Several methods have been reported for the determination of them such as spectrophotometry $[7,8]$, spectrofluorometry [9] and electroanalytical techniques [10,11]. In relation to the simultaneous analysis of $\mathrm{Cr}_{2} \mathrm{O}_{7}{ }^{2-}$ and $\mathrm{Ce}^{4+}$, Masin et al. have been reported a titrimetric method for the simultaneous determination of $\mathrm{Ce}^{4+}, \mathrm{MnO}_{4}^{-}$and $\mathrm{Cr}_{2} \mathrm{O}_{7}^{2-}$ using phosphate ion as precipitant of $\mathrm{Ce}^{4+}$ and $\mathrm{Fe}^{2+}$ as titrant [12]. To the best our knowledge, there is not any report for simultaneous determination of $\mathrm{Cr}_{2} \mathrm{O}_{7}^{2-}$ and $\mathrm{Ce}^{4+}$ using HPSAM and chemometrics methods. 
In recent years the usage of chemometrics methods in electroanalytical chemistry, as in other areas of analytical chemistry, has received considerable attention as these methods can help us with extraction of more information from experimental data. Applications of HPSAM and chemometrics methods have been frequently reported for the calibration of overlapped voltammetric signals [1316]. In the field of potentiometry, several methods have been reported based on flow injection system and titration using PLS, ANN and Kalman filter as modeling methods [17-21]. We are reported the first application of PLS and PCR multivariate calibration methods and HPSAM to the simultaneous kinetic-potentiometric determination of binary mixtures of hydrazine and its derivatives [22,23] and binary mixture of levodopa and carbidopa drugs [24]. The methods were based on the differences observed in the production rate of chloride ions in reaction of these species with $N$-chlorosuccinimide. The reaction rate of production of chloride ion was monitored by a chloride ion-selective electrode. Recently, we also reported the application of HPSAM, PLS and PCR methods for the simultaneous determination of binary mixtures of $\mathrm{Fe}(\mathrm{III})$ and $\mathrm{Al}(\mathrm{III})$ and ternary mixtures of $\mathrm{Fe}(\mathrm{III}), \mathrm{Al}(\mathrm{III})$ and $\mathrm{Zr}$ (IV) [25,26]. This method was based on the complex forming reaction of these metallic ions with fluoride ion that has a differential rate at certain reaction conditions. Therefore, the rate of fluoride-ion reaction with $\mathrm{Fe}(\mathrm{III}), \mathrm{Al}(\mathrm{III})$ and $\mathrm{Zr}$ (IV) was monitored by an fluoride ion-selective electrode (FISE).

This paper reports the first application of HPSAM, PCR and PLS to the simultaneous determination of oxidants binary mixtures such as $\mathrm{Cr}_{2} \mathrm{O}_{7}{ }^{2-}$ and $\mathrm{Ce}^{4+}$ using potentiometric technique. The methods are based on the difference observed in the oxidation reaction rate of $\mathrm{Fe}(\mathrm{II})$ to $\mathrm{Fe}$ (III) in the presence of $\mathrm{Ce}^{4+}$ and $\mathrm{Cr}_{2} \mathrm{O}_{7}{ }^{2-}$ as oxidants and complexing reaction between $\mathrm{Fe}$ (III) with fluoride ion at certain reaction conditions. The very fast response of the fluoride ion selective electrode (FISE) and its Nernstian behavior with respect to fluoride ions in acidic solutions indicated that this electrode might be employed effectively in kinetic studies of reactions involving changes in the fluoride ion concentration $[25,26]$. Therefore, rate of the complexing reaction of fluoride ion with $\mathrm{Fe}(\mathrm{III})$ was monitored by a FISE.

\section{Experimental}

\subsection{Apparatus and Software}

A solid-state Fluoride-selective electrode (Metrohm Model 6.0502.150) was used in conjunction with a double junction $\mathrm{Ag} / \mathrm{AgCl}$ reference electrode (Metrohm Model 6.0726.100), whose outer compartment was filled with a saturated $\mathrm{KCl}$ solution. The Metrohm Model 780 potentiometer, attached to a Pentium (IV) computer, was used for recording the kinetic potentiometric data. All measurements were carried out in a thermostated $(25.0 \pm$ $0.2^{\circ} \mathrm{C}$ ), double-walled reaction cell with continuous magnetic stirring. The electrode was stored in $1 \times 10^{-3}$ $\mathrm{mol} / \mathrm{L}$ potassium fluoride solution when not in use. For $\mathrm{pH}$ measurements, a Metrohm Model $780 \mathrm{pH}$ meter with a combination glass electrode was used. PLS and PCR analyses was performed using a MATLAB 7.0 software.

\subsection{Materials and Reagents}

All chemicals were of analytical reagent grade and doubly distilled water was used throughout. A stock solution of iron $\left(1000 \mu \mathrm{g} \mathrm{mL}^{-1}\right)$ was prepared by dissolving 0.524 $\mathrm{g}$ of iron (II) sulfate $\left(\mathrm{FeSO}_{4} \cdot 7 \mathrm{H}_{2} \mathrm{O}\right)$ in water and diluted to $100 \mathrm{~mL}$. Stock solutions $\mathrm{Ce}^{4+}$ and $\mathrm{Cr}_{2} \mathrm{O}_{7}{ }^{2-}$ were prepared in $100-\mathrm{mL}$ flasks by dissolving $0.2885 \mathrm{~g}$ of cerium sulfate tetrahydrate and $0.1369 \mathrm{~g}$ of potassium dichromate in water and diluting with water to the mark. Cerium(IV) sulfate and potassium dichromate and salts of $\mathrm{Fe}(\mathrm{II})$ and fluoride were purchased from Merck (Germany). Acetate buffer solution $(0.05 \mathrm{~mol} / \mathrm{L}, \mathrm{pH} 3.0)$ was prepared using acetic acid and $\mathrm{NaOH}$ solutions and adjusting its $\mathrm{pH}$ with a $\mathrm{pH}$ meter.

\subsection{Procedure}

Twenty five milliliters of double distilled water, $2.0 \mathrm{~mL}$ of buffer solution, $1.0 \mathrm{~mL}$ of standard fluoride solution $(0.1 \mathrm{~mol} / \mathrm{L})$ and $1.0 \mathrm{~mL}$ of $5 \times 10^{-3} \mathrm{~mol} / \mathrm{L}$ of iron (II) solution were added to the thermostated $\left(25.0 \pm 0.2^{\circ} \mathrm{C}\right)$ reaction cell. Five milliliter of the standard or sample solution of $\mathrm{Cr}_{2} \mathrm{O}_{7}{ }^{2-}, \mathrm{Ce}^{4+}$ or a mixture of them were injected into the cell quickly, and after the stabilization of the potential (about $30 \mathrm{~s}$ ), all data were recorded. The potential changes versus time were recorded at the time intervals of $1.0 \mathrm{~s}$. Synthetic samples containing different concentration ratios of $\mathrm{Cr}_{2} \mathrm{O}_{7}^{2-}$ and $\mathrm{Ce}^{4+}$ were prepared and standard additions of $\mathrm{Cr}_{2} \mathrm{O}_{7}{ }^{2-}$ were made. Simultaneous determination of $\mathrm{Cr}_{2} \mathrm{O}_{7}^{2-}$ and $\mathrm{Ce}^{4+}$ was conducted by recording the potential changes for each solution from 10 to $500 \mathrm{~s}$. After each run the cell was emptied and washed twice with doubly distilled water.

Using the standard analyte solutions, we can construct a calibration graph of $\left(10^{\Delta E / S}-1\right)$ versus concentration (fixed-time method) [22-27], where $\Delta E$ is the potential variation in a selected time interval $\Delta t$ and $S$ is the slope of the fluoride electrode response, which is determined periodically by successive additions of micro-amounts of $100 \mu \mathrm{L}$ of $1.0 \times 10^{-5}-1.0 \mathrm{~mol} / \mathrm{L}$ of $\mathrm{NaF}$ standard solutions in $25 \mathrm{~mL}$ of water mixed with $2 \mathrm{~mL}$ of buffer solution.

The simultaneous determination of $\mathrm{Cr}_{2} \mathrm{O}_{7}{ }^{2-}$ and $\mathrm{Ce}^{4+}$ standard solutions with HPSAM was performed by measuring the potential changes $(\Delta E)$ at 60 and $80 \mathrm{~s}$ after 
initiation of the reaction for each sample solution. Then plots of HPSAM of $\left(10^{\Delta E / S}-1\right)$ versus added concentration of $\mathrm{Ce}^{4+}$ were constructed for mixtures of $\mathrm{Cr}_{2} \mathrm{O}_{7}{ }^{2-}$ and $\mathrm{Ce}^{4+}$. Simultaneous determination of $\mathrm{Cr}_{2} \mathrm{O}_{7}{ }^{2-}$ and $\mathrm{Ce}^{4+}$ with PLS and PCR methods was performed by recording the potential for each solution from 10 to $500 \mathrm{~s}$.

\section{Results and Discussion}

It is require finding the system that shows different kinetic behavior for the reaction with $\mathrm{Cr}_{2} \mathrm{O}_{7}{ }^{2-}$ and $\mathrm{Ce}^{4+}$. It is well-known that the rate of oxidation of $\mathrm{Fe}^{2+}$ with $\mathrm{Cr}_{2} \mathrm{O}_{7}{ }^{2-}$ is much higher than that with $\mathrm{Ce}^{4+}[12]$. Therefore, we could use from this different kinetic behavior for simultaneous determination of $\mathrm{Cr}_{2} \mathrm{O}_{7}{ }^{2-}$ and $\mathrm{Ce}^{4+}$. The concept for the simultaneous analysis of $\mathrm{Cr}_{2} \mathrm{O}_{7}{ }^{2-}$ and $\mathrm{Ce}^{4+-}$ in this work is based on the difference in their oxidizing power. Preliminary studies showed that iron(II) ion as reagent at presence of fluoride ion using FISE is suitable for our purpose. Upon the addition of the oxidant $\left(\mathrm{Ce}^{4+}\right.$ and $\left.\mathrm{Cr}_{2} \mathrm{O}_{7}^{2-}\right)$ into solution of $\mathrm{Fe}^{2+}$ in the presence of $\mathrm{F}^{-}$, the oxidation reaction of $\mathrm{Fe}^{2+}$ by $\mathrm{Ce}^{4+}$ and $\mathrm{Cr}_{2} \mathrm{O}_{7}{ }^{2-}$ take place as follows:

$$
\begin{aligned}
& \mathrm{Ce}^{4+}+\mathrm{Fe}^{2+}+2 \mathrm{~F}^{-} \rightarrow\left[\mathrm{FeF}_{2}\right]^{+}+\mathrm{Ce}^{4+} \\
& \mathrm{Cr}_{2} \mathrm{O}_{7}^{2-}+2 \mathrm{Fe}^{2+}+4 \mathrm{~F}^{-}+14 \mathrm{H}^{+} \rightarrow \\
& 2\left[\mathrm{FeF}_{2}\right]^{3+}+2 \mathrm{Cr}^{3+}+7 \mathrm{H}_{2} \mathrm{O}
\end{aligned}
$$

When using this ions and FISE for monitoring difference in the reaction rate, the linear range and differences of reaction rate for both two species $\left(\mathrm{Cr}_{2} \mathrm{O}_{7}{ }^{2-}\right.$ and $\left.\mathrm{Ce}^{4+}\right)$ were suitable. In order to simultaneous kinetic potentiometric determination of $\mathrm{Cr}_{2} \mathrm{O}_{7}{ }^{2-}$ and $\mathrm{Ce}^{4+}$ by HPSAM, PCR and PLS a series of experiments were conducted to establish the optimum system to achieve maximum sensitivity. Therefore, all experimental parameters affecting the reaction rate of $\mathrm{Fe}^{2+}$ with $\mathrm{Ce}^{4+}$ and $\mathrm{Cr}_{2} \mathrm{O}_{7}{ }^{2-}$ (response time, concentration of $\mathrm{F}^{-}$and $\mathrm{Fe}^{2+}, \mathrm{pH}$, etc) were carefully optimized.

\subsection{Study of the Electrode Characteristics}

The very fast response of FISE and its Nernstian behavior toward fluoride ions in acidic solutions indicates that this electrode might be employed effectively in the kinetic studies of reactions involving changes in the fluoride ion concentration $[25,26]$. The characteristics of the fluoride-selective electrode in the $\mathrm{HNO}_{3}-\mathrm{H}_{3} \mathrm{BO}_{3}-\mathrm{NaOH}$ buffer were studied. In order to evaluate the operating characteristics of the FISE at $\mathrm{pH}<5$, calibration graphs were constructed for sodium fluoride in the concentration range of $1.0 \times 10^{-5}-1.0 \times 10^{-1} \mathrm{~mol} / \mathrm{L}$ at $\mathrm{pHs} 4.0,3.0,2.5$ and 2.0. The slope was found to be $56.9 \mathrm{mV} /$ decade and remained almost constant to $0.2 \mathrm{mV}$ over 6 months of usage in this system at $\mathrm{pH}$ 3.0.

\subsection{Effect of Fluoride Concentration}

The effect of $\mathrm{F}^{-}$concentration over the ranges of $1.0 \times$ $10^{-5}-1.0 \times 10^{-1} \mathrm{~mol} / \mathrm{L}$ fluoride ion on the linear range of calibration graph and reaction rate with $\mathrm{Fe}(\mathrm{II})$ was investigated (Figure 1). The results also indicate that the concentration of $\mathrm{F}^{-}$has a great effect on the linear range and the change potential value. When the concentration of $\mathrm{F}^{-}$ is low, a gradual slope in the calibration graph is realized while a high concentration of $\mathrm{F}^{-}$produces is high a steep slope in the calibration graph. So the fluoride concentration must be in excess, but by increasing the fluoride concentration, the potential change is decreased and the sensitivity is lower. Since, maximum differences in kinetic behaviour of $\mathrm{Fe}$ (III) (resulted from oxidation reaction of $\mathrm{Fe}^{2+}$ to $\mathrm{Fe}^{3+}$ by $\mathrm{Ce}^{4+}$ and $\mathrm{Cr}_{2} \mathrm{O}_{7}^{2-}$ ) and was observed in concentration of $1.0 \times 10^{-3} \mathrm{~mol} \mathrm{~L}^{-1}$ fluoride and both species also had larger values of potential change $(\Delta \mathrm{E})$ in this concentration. Therefore, a concentration of $1.0 \times 10^{-3} \mathrm{~mol} / \mathrm{L}$ fluoride was selected as the optimum concentration for further studies.

\subsection{Effect of $\mathrm{Fe}^{2+}$ Concentration}

The effect of $\mathrm{Fe}^{2+}$ concentration over the ranges of $1.0 \times$ $10^{-5}-1.0 \times 10^{-1} \mathrm{~mol} / \mathrm{L} \mathrm{Fe}^{2+}$ ion on the reaction rate of $\mathrm{Fe}^{2+}$ with $\mathrm{Ce}^{4+}$ and $\mathrm{Cr}_{2} \mathrm{O}_{7}{ }^{2-}$ and linear range of calibration graph was investigated (Figure 2). The results have shown that the increase of $\mathrm{Fe}^{2+}$ concentration, up to $5.0 \times$ $10^{-3} \mathrm{~mol} / \mathrm{L}$, causes an increase in the reaction rate of $\mathrm{Fe}^{2+}$ with both $\mathrm{Ce}^{4+}$ and $\mathrm{Cr}_{2} \mathrm{O}_{7}{ }^{2-}$ and the potential change, but decreased at higher concentrations. There- fore, a concentration of $5.0 \times 10^{-3} \mathrm{~mol} / \mathrm{L} \mathrm{Fe}^{2+}$ ion was selected as the optimum concentration for further studies.

\subsection{Effect of $\mathrm{pH}$}

Acidity of the solution influences potential response of

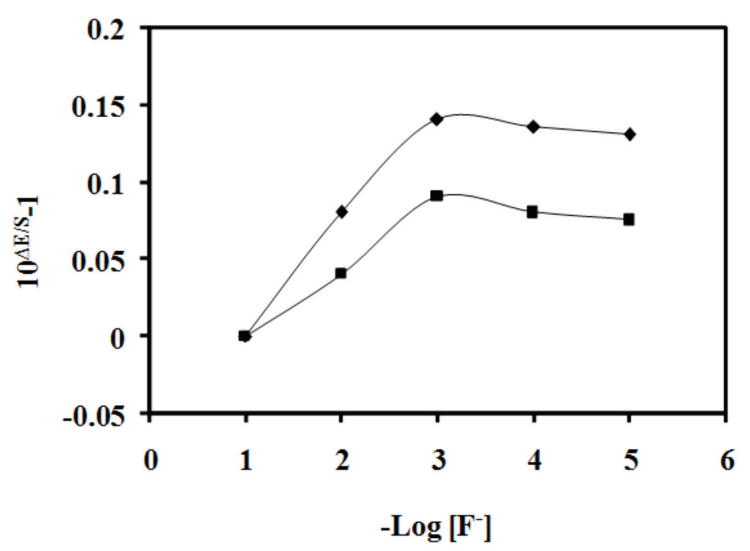

Figure 1. Effect of $\mathrm{F}^{-}$concentration on the reaction of $\mathrm{F}^{-}$ and $\mathrm{Fe}^{2+}$ with $5.0 \mu \mathrm{g} / \mathrm{mL}$ of $\mathrm{Ce}^{4+}$ (घ) and $10.0 \mu \mathrm{g} / \mathrm{mL}$ of $\mathrm{Cr}_{2} \mathrm{O}_{7}{ }^{2-}(\triangleleft)$. Conditions: $5 \times 10^{-3} \mathrm{M} \mathrm{Fe}^{2+}, \mathrm{pH} \mathrm{3.0,25}{ }^{\circ} \mathrm{C}$. 


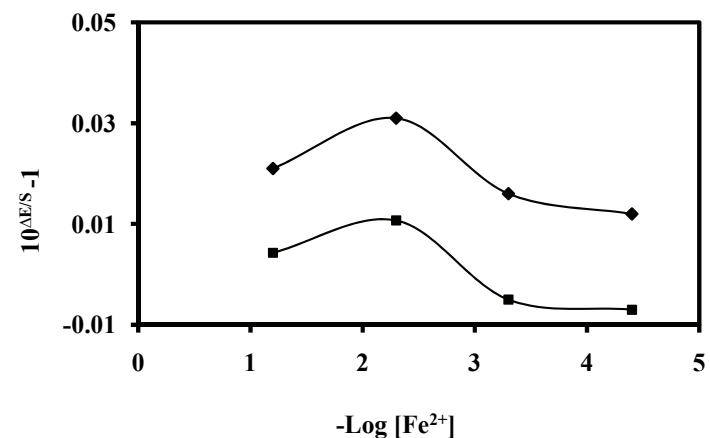

Figure 2. Effect of $\mathrm{Fe}^{2+}$ concentration on the reaction of $\mathrm{F}^{-}$ and $\mathrm{Fe}^{2+}$ with $5.0 \mu \mathrm{g} / \mathrm{mL}$ of $\mathrm{Ce}^{4+}$ (घ) and $10.0 \mu \mathrm{g} / \mathrm{mL}$ of $\mathrm{Cr}_{2} \mathrm{O}_{7}{ }^{2-}(\bullet)$. Conditions: $1 \times 10^{-3} \mathrm{M} \mathrm{F}^{-}, \mathrm{pH} \mathrm{3.0,25}{ }^{\circ} \mathrm{C}$.

FISE, the oxidation reaction rate of $\mathrm{Fe}^{2+}$ with $\mathrm{Ce}^{4+}$ and $\mathrm{Cr}_{2} \mathrm{O}_{7}{ }^{2-}$ and complextion reaction rate of $\mathrm{F}^{-}$with $\mathrm{Fe}^{3+}$. The results show that maximum difference in kinetic behavior of $\mathrm{Fe}^{3+}$ was observed at $\mathrm{pH} 3.0$ (Figure 3). In addition, $\mathrm{Fe}^{3+}$ had larger values of potential change $(\Delta E)$ in this $\mathrm{pH}$. Above $\mathrm{pH} 3.0$, the potential change decreased evidently due to the occurrence of the hydrolysis reaction competing with the complexation between fluoride and $\mathrm{Fe}^{3+}$, and under $\mathrm{pH} 3.0$, the potential change decreased too, probably owing to the formation of hydrogen fluoride, to which the fluoride electrode is insensitive. Thus, $\mathrm{pH}$ of 3.0 was selected as the optimum $\mathrm{pH}$ for further studies.

\subsection{Composition Effect of Ground Buffer Solution}

The change of potential value $(\Delta E)$ for reaction of $\mathrm{Fe}^{2+}$ with $\mathrm{Ce}^{4+}$ and $\mathrm{Cr}_{2} \mathrm{O}_{7}^{2-}$ in the presence of certain amount fluoride ion in different acidic solutions was investigated (Table 1). The results have shown that in the solution of $\mathrm{HNO}_{3}-\mathrm{H}_{3} \mathrm{BO}_{3}(\mathrm{pH} 3.0), \Delta E_{\mathrm{Fe}}{ }^{3+}$ has larger values. According to obtained results, the $0.1 \mathrm{~mol} \mathrm{~L}^{-1}$ boric acid$0.1 \mathrm{~mol} / \mathrm{L}$ nitric acid- mixed solution $(\mathrm{pH} 3.0)$ containing $1.0 \times 10^{-3} \mathrm{~mol} / \mathrm{L}$ fluoride was chosen as the ground buffer solutions.

\subsection{Temperature Effect of Reaction Rate}

The temperature of solution evidently affects the reaction rate of the kinetic reaction. But higher temperatures do not have a positive effect on the reaction of $\mathrm{Fe}^{2+}$ with $\mathrm{Ce}^{4+}$ and $\mathrm{Cr}_{2} \mathrm{O}_{7}{ }^{2-}$ and complexing reaction of $\mathrm{Fe}^{3+}$ with fluoride. Therefore, the temperature of solution was kept at $25 \pm 0.2^{\circ} \mathrm{C}$ by thermostatic water bath in all of the measurements.

\subsection{Potential-Time Behavior}

The potential-time behavior of reactions of $\mathrm{Fe}^{2+}$ with
$\mathrm{Ce}^{4+}$ and $\mathrm{Cr}_{2} \mathrm{O}_{7}^{2-}$ in the presence of $\mathrm{F}^{-}$under the optimized conditions is shown in Figure 1. Figure 2 shows typical reaction curves for the reaction of $\mathrm{Fe}^{2+}$ with $\mathrm{Ce}^{4+}$ and $\mathrm{Cr}_{2} \mathrm{O}_{7}{ }^{2-}$ at different concentrations. As can be seen in Figures 4 and $\mathbf{5}$, the reaction of $\mathrm{Cr}_{2} \mathrm{O}_{7}{ }^{2-}$ is faster $\mathrm{Ce}^{4+}$ and was almost completed in $60 \mathrm{~s}$ after initial reaction but the reaction of $\mathrm{Ce}^{4+}$ was completed almost in $500 \mathrm{~s}$. This difference in the reaction rates allowed us to design the HPSAM, PCR and PLS methods for simultaneous determination of $\mathrm{Ce}^{4+}$ and $\mathrm{Cr}_{2} \mathrm{O}_{7}{ }^{2-}$. Characteristics of calibration graphs for the determination of $\mathrm{Ce}^{4+}$ and $\mathrm{Cr}_{2} \mathrm{O}_{7}{ }_{7}^{2-}$, under the optimum conditions, are also given in Table 2. Therefore, above difference mentioned in the reaction rates allowed us to design the HPSAM, PCR and PLS a method for simultaneous determination of $\mathrm{Ce}^{4+}$ and $\mathrm{Cr}_{2} \mathrm{O}_{7}^{2-}$, in the concentration ranges of 1.0-30.0 and 0.1$20.0 \mu \mathrm{g} / \mathrm{mL}$, respectively.

\subsection{Requirements for Applying HPSAM}

The basis of using HPSAM for treating kinetic data under the conditions that the reaction of one component is

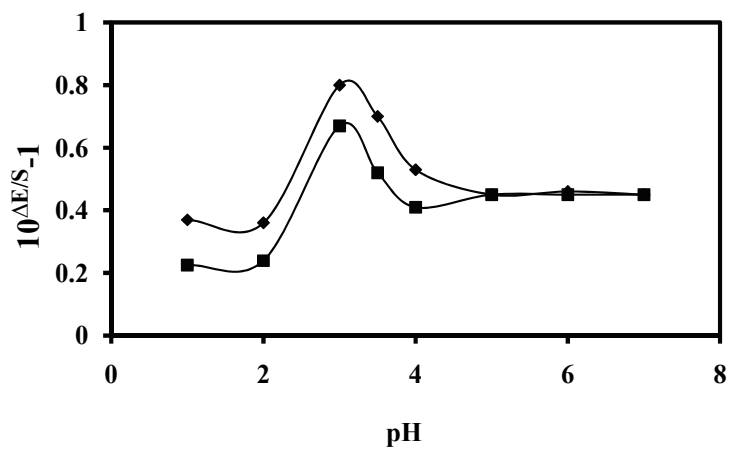

Figure 3. Effect of $\mathrm{pH}$ on the reaction of $\mathrm{F}^{-}$and $\mathrm{Fe}^{2+}$ with $5.0 \mu \mathrm{g} / \mathrm{mL}$ of $\mathrm{Ce}^{4+}$ (घ) and $10.0 \mu \mathrm{g} / \mathrm{mL} \mathrm{of} \mathrm{Cr}_{2} \mathrm{O}_{7}{ }^{2-}$ (४). Conditions: $1 \times 10^{-3} \mathrm{MF}^{-}, 5 \times 10^{-3} \mathrm{M} \mathrm{Fe}^{2+}, 25^{\circ} \mathrm{C}$.

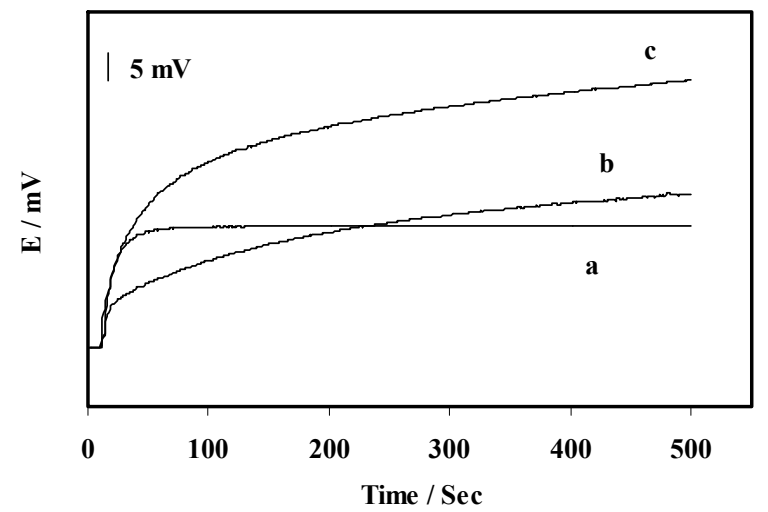

Figure 4. Potential-time curves for the reaction of $\mathrm{F}^{-}$and $\mathrm{Fe}^{2+}$ with $10.0 \mu \mathrm{g} / \mathrm{mL}$ of $\mathrm{Cr}_{2} \mathrm{O}_{7}{ }^{2-}(\mathrm{a}), 5.0 \mu \mathrm{g} / \mathrm{mL}$ of $\mathrm{Ce}^{4+}$ (b) and mixture of them (c). 
Table 1. The values of $\Delta E$ for reaction of $10 \mu \mathrm{g} / \mathrm{mL} \mathrm{of} \mathrm{Fe}^{2+}$ with $\mathrm{Ce}(\mathrm{IV})$ and $\mathrm{Cr}_{2} \mathrm{O}_{7}^{2-}$ in the presence of $1.0 \times 10^{-3} \mathrm{M} \mathrm{F}^{-}$ ion in different acid solutions $(\mathrm{pH}=3.0)$.

\begin{tabular}{lcccc}
\hline Acid solution & $\mathrm{H}_{3} \mathrm{PO}_{4}-\mathrm{H}_{3} \mathrm{BO}_{3}$ & $\mathrm{KCl}-\mathrm{HCl}$ & $\begin{array}{c}\mathrm{HNO}_{3-}^{-} \\
\mathrm{CH}_{3} \mathrm{COOH}\end{array}$ & $\mathrm{HNO}_{3}-\mathrm{H}_{3} \mathrm{BO}_{3}$ \\
\hline$\triangle E_{\mathrm{Fe}}{ }^{3+}$ (for & 2.3 & 7.5 & 8.5 & 13.0 \\
$\left.\mathrm{Cr}_{2} \mathrm{O}_{7}^{2-}\right) / \mathrm{mv}$ & 2.3 & 5.5 & 6.7 & 10.4 \\
$\begin{array}{l}\triangle E_{\mathrm{Fe}}{ }^{3+} \text { (for } \\
\mathrm{Ce}^{4+} / \mathrm{mv}\end{array}$ & 1.8 & 5.8 & \\
\hline
\end{tabular}

Table 2. Characteristics of calibration graphs for the determination of $\mathrm{Ce}^{4+}$ and $\mathrm{Cr}_{2} \mathrm{O}_{7}{ }^{2-}$.

\begin{tabular}{cccccc}
\hline Species & $\begin{array}{c}\text { Linear } \\
\text { range }\end{array}$ & Slope & Intercept & $\begin{array}{c}\text { Correlation } \\
\text { coefficient }\end{array}$ & $\begin{array}{c}\text { Detection } \\
\text { limit }\end{array}$ \\
\hline & $(\mu \mathrm{g} / \mathrm{mL})$ & $(\mathrm{mL} / \mu \mathrm{g})$ & & & \\
$(\mu \mathrm{g} / \mathrm{mL})$ & \\
$\mathrm{Ce}^{4+}$ & $1.0-30.0$ & 0.0681 & 0.0177 & $\begin{array}{c}0.9995(\mathrm{n}= \\
10)\end{array}$ & 0.450 \\
$\mathrm{Cr}_{2} \mathrm{O}_{7}^{2-}$ & $0.1-20.0$ & 0.1119 & 0.2975 & $\begin{array}{c}0.9994(\mathrm{n}= \\
10)\end{array}$ & 0.086 \\
\hline
\end{tabular}

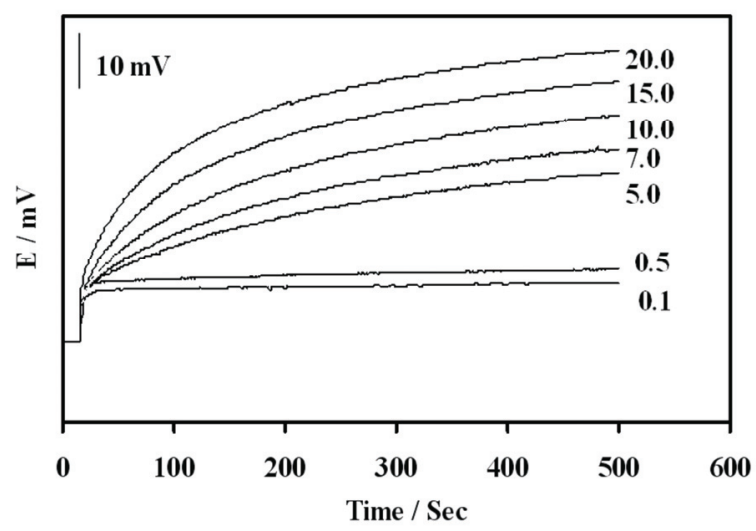

(a)

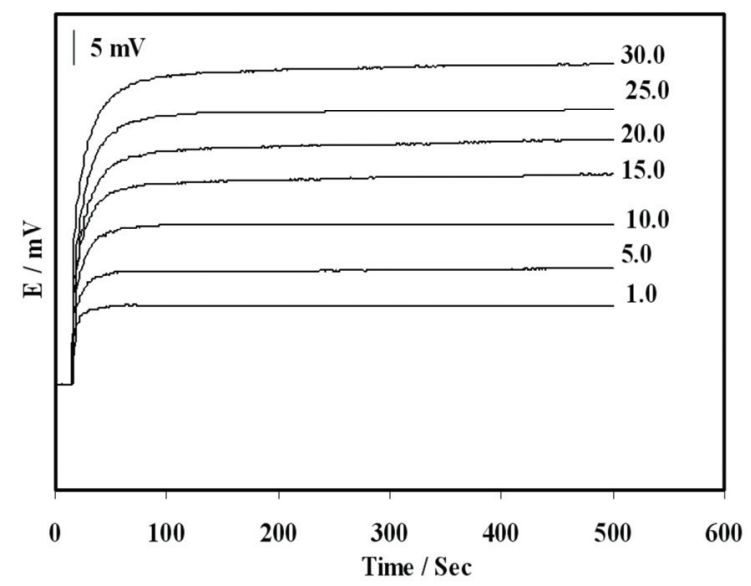

(b)

Figure 5. Typical potential-time curves for the reaction of $\mathrm{F}^{-}$and $\mathrm{Fe}^{+2}$ with $\mathrm{Ce}^{4+}$ (a) and $\mathrm{Cr}_{2} \mathrm{O}_{7}^{2-}$ (b) at different concentrations $(\mu \mathrm{g} / \mathrm{mL})$.

completed, while that of other component is not com- pleted yet, is described below. In this case, the vari- ables to be fixed were the time variables $t_{1}$ and $t_{2}$, at which the product of the reaction of $\mathrm{Ce}^{4+}$ had the same amount of $\left(10^{\Delta \mathrm{E} / \mathrm{S}}-1\right)$ over the range between these two times, and also there is an appropriate difference between the slopes of the calibration lines.

Considering a binary mixture of $\mathrm{Ce}^{4+}$ and $\mathrm{Cr}_{2} \mathrm{O}_{7}{ }^{2-}$, for example, assume that the amount of $\mathrm{R}\left(10^{\Delta E / S}-1\right)$ of the oxidation in the reaction of $\mathrm{Fe}^{2+}$ with $\mathrm{Ce}^{4+}$ and then complexation in the reaction of $\mathrm{Fe}^{3+}$ with $\mathrm{F}^{-}$at time variables $t_{1}$ and $t_{2}$ are $P_{i}$ and $Q_{i}$, respectively, while those for the $\mathrm{Cr}_{2} \mathrm{O}_{7}{ }^{2-}-\mathrm{Fe}^{2+}-\mathrm{F}^{-}$reaction under the same conditions are $P$ and $Q$, respectively (Figure 6). They are equal in this case.

The following equations show the relation between them:

For $\mathrm{Ce}^{4+}: \quad Q_{i}=P_{i}+m_{i} t_{j}\left(t_{1} \leq t_{j} \leq t_{2} ; \quad i=0,1, \ldots, n\right)(1)$

For $\mathrm{Cr}_{2} \mathrm{O}_{7}{ }^{2-}: \quad Q=P+m t_{j}(m=0)$

where subscripts $i$ and $j$ denote different solutions for $n$ additions of $\mathrm{Ce}^{4+}$ concentration prepared to apply to HPSAM and the time comprising the $t_{1}-t_{2}$ range, respectively.

Thus, the overall amounts of $\left(10^{\Delta E / S}-1\right)$ (or $R$ ) of the $\mathrm{Ce}^{4+}-\mathrm{Cr}_{2} \mathrm{O}_{7}{ }^{2-}$ mixture are:

$$
\begin{array}{lll}
\text { At } & t_{1} & R t_{1}=P+P_{i} \\
\text { At } & t_{2} & R t_{2}=Q+Q_{i}
\end{array}
$$

Simultaneous kinetic determination of concentration of $\mathrm{Ce}^{4+}$ and $\mathrm{Cr}_{2} \mathrm{O}_{7}{ }^{2-}$ by HPSAM requires the selection of two times $t_{1}$ and $t_{2}$. To select the appropriate times, the following principles were observed. At the two selected times $t_{1}$ and $t_{2}$, the amount of $R$ of the $\mathrm{Ce}^{4+}$ must be linear with the concentrations, and the amount of $R$ for $\mathrm{Fe}^{3+}$ must remain constant even if the $\mathrm{Cr}_{2} \mathrm{O}_{7}{ }^{2-}$ concentrations are changed. The amount of $R$ for the mixture of $\mathrm{Ce}^{4+}$ and $\mathrm{Cr}_{2} \mathrm{O}_{7}^{2-}$ should be equal to the sum of individual $R s$ of the two compounds. In addition, the slope difference of the two straight lines obtained at both $t_{1}$ and $t_{2}$ must be

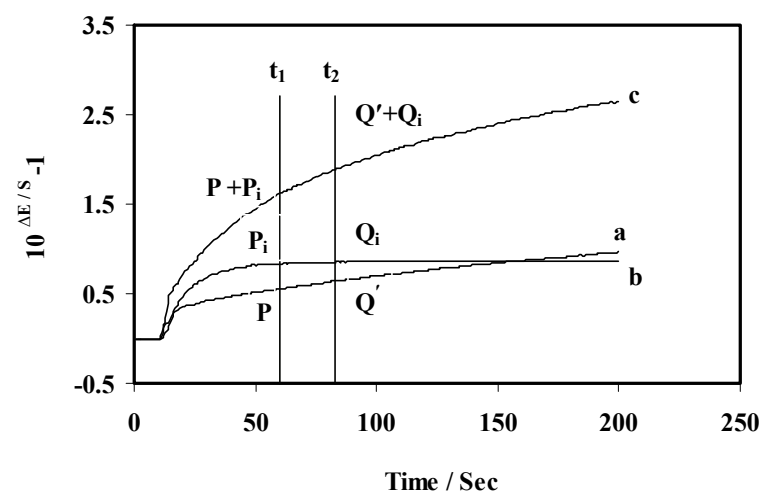

Figure 6. Plot of potential changes $\left(10^{\Delta E / S}-1\right)$ for the reaction of $\mathrm{F}^{-}$and $\mathrm{Fe}^{2+}$ with $10.0 \mu \mathrm{g} / \mathrm{mL}$ of $\mathrm{Ce}^{4+}$ (a), $5.0 \mu \mathrm{g} / \mathrm{mL}$ of $\mathrm{Cr}_{2} \mathrm{O}_{7}{ }^{2-}$ (b) and mixture of them (c). 
as large as possible to achieve good accuracy. Then known amounts of $\mathrm{Ce}^{4+}$ are successively added to the mixture and resulting potential changes are measured at the two times and expressed:

$$
\begin{aligned}
& R_{t 1}=\left(10^{\Delta E(t 1) / S}-1\right)_{t 1}=P_{0}+P+M_{t 1} C_{i} \\
& R_{t 2}=\left(10^{\Delta E(t 2) / S}-1\right)_{t 2}=Q_{0}+Q+M_{t 2} C_{i}
\end{aligned}
$$

where $\Delta E\left(t_{1}\right)$ and $\Delta E\left(t_{2}\right)$ are the potential changes measured at $t_{1}$ and $t_{2}$, respectively. $P_{0}$ and $Q_{0}$ are the amounts of $R$ for $\mathrm{Ce}^{4+}$ at a sample at $t_{1}$ and $t_{2}$, respectively. $P$ and $Q$ are the amounts of $R$ for $\mathrm{Cr}_{2} \mathrm{O}_{7}{ }^{2-}$ at $t_{1}$ and $t_{2}$, respectively (Figure 7).

$M_{t 1}$ and $M_{t 2}$ are the slopes of the standard addition calibration lines at $t_{1}$ and $t_{2}$, respectively. $C_{i}$ is the added $\mathrm{Ce}^{4+}$ concentration. The two obtained straight lines intersect at the so-called H-point $\left(-C_{H}, R_{H}\right)$, which at point $\mathrm{H}$ (Figure 7), since $R_{t 1}=R_{t 2}, H\left(-C_{H}, R_{H}\right) \approx\left(-C_{\text {Ceric }}, R_{D i-}\right.$ chromate) from Equations (1) and (2) we have:

$$
\begin{array}{r}
P_{0}+P+M_{t 1}\left(-C_{H}\right)=Q_{0}+Q+M_{t 2}\left(-C_{H}\right) \\
-C_{H}=\left[(Q-P)+\left(Q_{0}-P_{0}\right)\right] /\left(M_{t 1}-M_{t 2}\right)
\end{array}
$$

as species $\mathrm{Cr}_{2} \mathrm{O}_{7}{ }^{2-}$ is assumed not to evolve over the considered range of time,

$$
Q=P
$$

and

$$
C_{H}=\left(Q_{0}-P_{0}\right) /\left(M_{t 1}-M_{t 2}\right)
$$

which is equivalent to the existing $C_{\text {Ceric }}\left(=P_{0} / M_{t 1}=Q_{0} /\right.$ $M_{t 2}$ ). Combining this with Equation (5) yields $R_{H}=P$. The overall equation for the potential at the H-point is simply represented as:

$$
Q=P=R_{H}=R_{F e}
$$

The intersection of the straight lines (Equations (5) and (6) directly yields the unknown $\mathrm{Ce}^{4+}$ concentration $\left(C_{\text {Ceric }}\right)$ and the $R$ for $\mathrm{Cr}_{2} \mathrm{O}_{7}{ }^{2-}$ species $\left(R_{\text {Dichromate }}\right)$ corresponding to $t_{1}$ and $t_{2}$ in the original samples, as the two times were chosen in such a way that the later species had the same $R$ at both times. This analytical signal enables us to calculate the concentration of $\mathrm{Cr}_{2} \mathrm{O}_{7}{ }^{2-}$ from a calibration curve.

Since $\mathrm{Ce}^{4+}$ is selected as the analyte, it is possible to select several pairs of time ranges which present the same $R$ for $\mathrm{Cr}_{2} \mathrm{O}_{7}{ }^{2-}$. Some of the selected time pairs were $60-80,80-110,150-200,250-300$ and 350-420 s. Greater time increments caused higher sensitivity and steeper slopes of the two time axes, as shown previously by Campins-Falco et al. [29]. Also, the accuracy of determinations was affected by the slope increments of $\mathrm{H}-$ point plots. However, the time pair that gives the greatest slope increment, lower error, and shortest analysis time was selected. For this reason, the time pair of 60-80 s as the most suitable times was employed.

A summary of the results obtained for various analyte concentrations is given in Tables 3 and 4. The concentration was calculated directly by solving a system of equations of two straight lines. $\mathrm{Cr}_{2} \mathrm{O}_{7}{ }^{2-}$ concentrations were calculated in each test solution by the calibration method with a single standard and ordinate value of $R$.

\subsection{Multivariate Calibration}

Multivariate calibration consists of establishment of a relationship between matrices of chemical data. These methods are based on a first calibration step in which a mathematical model is built using a chemical data set

\begin{tabular}{|c|c|c|c|c|c|}
\hline \multirow{2}{*}{$R-C$ equation } & \multirow{2}{*}{$\mathrm{r}$} & \multicolumn{2}{|c|}{$\begin{array}{c}\text { Spiked } \\
(\mu \mathrm{g} / \mathrm{mL})\end{array}$} & \multicolumn{2}{|c|}{ Found $(\mu \mathrm{g} / \mathrm{mL})$} \\
\hline & & $\mathrm{Ce}^{4+}$ & $\mathrm{Cr}_{2} \mathrm{O}_{7}^{2-}$ & $\mathrm{Ce}^{4+}$ & $\mathrm{Cr}_{2} \mathrm{O}_{7}^{2-}$ \\
\hline $\begin{array}{l}R_{80}=0.0322 C_{i}+ \\
0.4665\end{array}$ & 0.9994 & 5.0 & 2.0 & $4.90 \pm 0.10$ & $2.12 \pm 0.08$ \\
\hline $\begin{array}{l}R_{60}=0.0509 C_{i}+ \\
0.5069\end{array}$ & 0.9990 & & & & \\
\hline $\begin{array}{l}R_{80}=0.0209 C_{i}+ \\
0.3056\end{array}$ & 0.9990 & 3.0 & 3.0 & $3.14 \pm 0.11$ & $3.10 \pm 0.10$ \\
\hline $\begin{array}{l}R_{60}=0.0286 C_{i}+ \\
0.3334\end{array}$ & 0.9999 & & & & \\
\hline $\begin{array}{l}R_{80}=0.0164 C i+ \\
0.5153\end{array}$ & 0.9991 & 5.0 & 10.0 & $5.16 \pm 0.13$ & $9.85 \pm 0.18$ \\
\hline $\begin{array}{l}R_{60}=0.0239 C i+ \\
0.5880\end{array}$ & 0.9990 & & & & \\
\hline $\begin{array}{l}R_{80}=0.0057 C i+ \\
0.9900\end{array}$ & 0.9930 & 13.0 & 15.0 & $13.20 \pm 0.2$ & $\begin{array}{c}15.32 \pm \\
0.21\end{array}$ \\
\hline $\begin{array}{l}R_{60}=0.0153 C i+ \\
1.1312\end{array}$ & 0.9970 & & & & \\
\hline $\begin{array}{l}R_{80}=0.0052 C i+ \\
1.5450\end{array}$ & 0.9999 & 20.0 & 10.0 & $\begin{array}{c}19.76 \pm \\
0.28\end{array}$ & $\begin{array}{c}10.12 \pm \\
0.15\end{array}$ \\
\hline $\begin{array}{l}R_{60}=0.0155 C i+ \\
1.6895\end{array}$ & 0.9930 & & & & \\
\hline $\begin{array}{l}R_{80}=0.0101 C i+ \\
1.9061\end{array}$ & 0.9950 & 25.0 & 15.0 & $\begin{array}{c}24.70 \pm \\
0.24\end{array}$ & $\begin{array}{c}15.38 \pm \\
0.28\end{array}$ \\
\hline $\begin{array}{l}R_{60}=0.0058 C i+ \\
1.8365\end{array}$ & 0.9995 & & & & \\
\hline $\begin{array}{l}R_{80}=0.0014 C i+ \\
0.9954\end{array}$ & 0.9920 & 15.0 & 5.0 & $\begin{array}{c}15.27 \pm \\
0.23\end{array}$ & $5.34 \pm 0.15$ \\
\hline $\begin{array}{l}R_{60}=0.0107 \mathrm{Ci}+ \\
1.0391\end{array}$ & 0.9992 & & & & \\
\hline
\end{tabular}

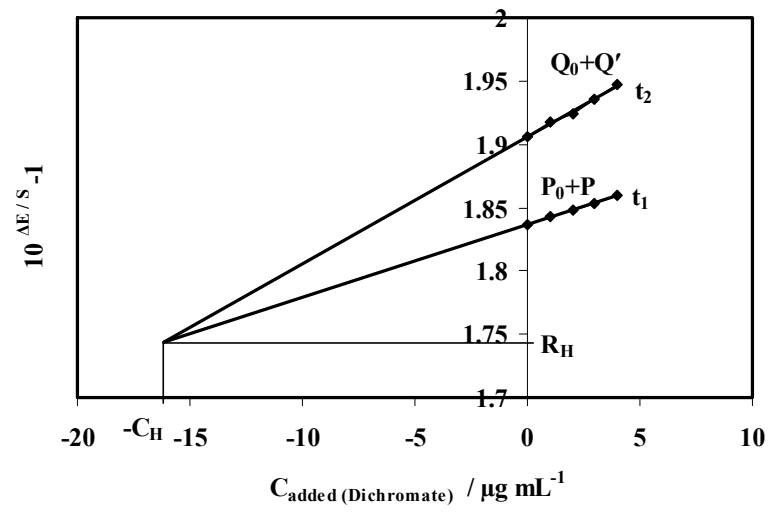

Figure 7. Plot of HPSAM for simultaneous determination of a mixture of $\mathrm{Cr}_{2} \mathrm{O}_{7}{ }^{2-}(15 \mu \mathrm{g} / \mathrm{mL})$ and $\mathrm{Ce}^{4+}(25 \mu \mathrm{g} / \mathrm{mL})$.

Table 3. Results of several experiments for analysis of $\mathrm{Ce}^{4+}$ and $\mathrm{Cr}_{2} \mathrm{O}_{7}{ }^{2-}$ mixtures in different concentration ratios using HPSAM $\left(T=25^{\circ} \mathrm{C}\right)$. 
Table 4. Results of six replicate experiments for analysis of $\mathrm{Ce}^{4+}$ and $\mathrm{Cr}_{2} \mathrm{O}_{7}{ }^{2-}$ mixture using HPSAM $\left(\mathrm{T}=25^{\circ} \mathrm{C}\right)$.

\begin{tabular}{|c|c|c|c|c|c|}
\hline \multirow{2}{*}{$R-C$ equation } & \multirow{2}{*}{$r$} & \multicolumn{2}{|c|}{ Spiked $(\mu \mathrm{g} / \mathrm{mL})$} & \multicolumn{2}{|c|}{ Found $(\mu \mathrm{g} / \mathrm{mL})$} \\
\hline & & $\mathrm{Ce}^{4+}$ & $\mathrm{Cr}_{2} \mathrm{O}_{7}^{2-}$ & $\mathrm{Ce}^{4+}$ & $\mathrm{Cr}_{2} \mathrm{O}_{7}^{2-}$ \\
\hline $\begin{array}{l}R_{80}=0.1090 C_{i} \\
+1.0720\end{array}$ & 0.9902 & 13 & 15 & $12.98(99.8)$ & $15.51(103.4)$ \\
\hline $\begin{array}{l}R_{60}=0.0046 C_{i} \\
+0.9736\end{array}$ & 0.9900 & & & & \\
\hline $\begin{array}{l}R_{80}=0.0094 C_{i} \\
+1.0276\end{array}$ & 0.9980 & 13 & 15 & $12.79(98.3)$ & $14.75(98.3)$ \\
\hline $\begin{array}{l}R_{60}=0.0040 C_{i} \\
+0.9479\end{array}$ & 0.9999 & & & & \\
\hline $\begin{array}{l}R_{80}=0.0153 C_{i} \\
+1.1312\end{array}$ & 0.9980 & 13 & 15 & $\begin{array}{c}13.10(100 . \\
7)\end{array}$ & $14.80(98.6)$ \\
\hline $\begin{array}{l}R_{60}=0.0057 C_{i} \\
+0.9900\end{array}$ & 0.9933 & & & & \\
\hline $\begin{array}{l}R_{80}=0.0104 C_{i} \\
+1.0300\end{array}$ & 0.9990 & 13 & 15 & $12.70(97.7)$ & $14.40(96.0)$ \\
\hline $\begin{array}{l}R_{60}=0.0056 C_{i} \\
+0.9611\end{array}$ & 0.9930 & & & & \\
\hline $\begin{array}{l}R_{80}=0.0154 C_{i} \\
+1.1488\end{array}$ & 0.9930 & 13 & 15 & $\begin{array}{c}13.30(102 . \\
3)\end{array}$ & $14.80(98.6)$ \\
\hline $\begin{array}{l}R_{60}=0.0056 C_{i} \\
+1.0034\end{array}$ & 0.9940 & & & & \\
\hline $\begin{array}{l}R_{80}=0.0156 C_{i} \\
+1.0520\end{array}$ & 0.9990 & 13 & 15 & $12.60(96.9)$ & $15.0(100.0)$ \\
\hline $\begin{array}{l}R_{60}=0.0055 C_{i} \\
+0.9567\end{array}$ & 0.9940 & & & & \\
\hline Mean & & & & 13.01 & 14.87 \\
\hline SD & & & & 0.28 & 0.39 \\
\hline RSD (\%) & & & & 2.16 & 2.60 \\
\hline
\end{tabular}

(e.g., potential values) and a concentration matrix data set [30-34]. The calibration is followed by a prediction set in which this model is used to estimate unknown concentrations of a mixture from kinetic profile. Multivariate calibration methods are being successfully applied to the multi-component kinetic determination to overcome some of the drawbacks of classical methods. The theories and applications of chemometrics methods such as PCR and PLS, to the analysis of multi-component mixtures, have been discussed by several workers [3135]. PCR and PLS modeling are powerful multivariate statistical tools, which are successfully applied to the quantitative analysis of spectrochemical and electrochemical data [33-36]. The first step in the simultaneous determination of the species by PCR and PLS methodologies involves the construction of calibration matrix for the binary mixture of $\mathrm{Ce}^{4+}$ and $\mathrm{Cr}_{2} \mathrm{O}_{7}^{2-}$. For constructing the calibration set, factorial design was applied to five levels in order to extract a great deal of quantitative information, using only a few experimental trials. In this research, a synthetic set of 34 solutions, including different concentrations of $\mathrm{Ce}^{4+}$ and $\mathrm{Cr}_{2} \mathrm{O}_{7}{ }^{2-}$, was prepared. A collection of 26 solutions was selected as the calibration set (Table 5) and the other 8 solutions were used as the prediction set (Table 6). Their composition was randomly designed to obtain more information from the calibration procedure. Changes in the solution potential were recorded during a time period of 500 seconds.

To select the number of factors in the PCR and PLS algorithm, as a cross-validation method, leaving out one sample method was employed [37]. The prediction error was calculated for each species of the prediction set. This error was expressed as the prediction residual error sum of squares (PRESS):

$$
\text { PRESS }=\sum_{i=1}^{m}\left(\hat{\mathrm{C}}_{\mathrm{i}}-C_{i}\right)^{2}
$$

Where $\mathrm{m}$ is the total number of calibration sample, $\hat{C}_{i}$ represents the estimated concentration while $C_{i}$ is the reference concentration for the $i$ th sample left out of the

Table 5. Calibration set for constructing PCR and PLS methods in determination of $\mathrm{Ce}^{4+}$ and $\mathrm{Cr}_{2} \mathrm{O}_{7}{ }^{2-}(\mu \mathrm{g} / \mathrm{mL})$.

\begin{tabular}{cccccc}
\hline Sample & $\mathrm{Ce}^{4+}$ & $\mathrm{Cr}_{2} \mathrm{O}_{7}^{2-}$ & Sample & $\mathrm{Ce}^{4+}$ & $\mathrm{Cr}_{2} \mathrm{O}_{7}^{2-}$ \\
\hline 1 & 5.0 & 2.0 & 14 & 22.0 & 15.0 \\
2 & 5.0 & 6.0 & 15 & 22.0 & 18.0 \\
3 & 5.0 & 12.0 & 16 & 1.0 & 0.5 \\
4 & 5.0 & 20.0 & 17 & 1.0 & 6.0 \\
5 & 10.0 & 10.0 & 18 & 1.0 & 4.0 \\
6 & 10.0 & 15.0 & 19 & 25.0 & 17.0 \\
7 & 10.0 & 19.0 & 20 & 25.0 & 19.0 \\
8 & 13.0 & 17.0 & 21 & 25.0 & 20.0 \\
9 & 13.0 & 20.0 & 22 & 18.0 & 7.0 \\
10 & 3.0 & 3.0 & 23 & 18.0 & 15.0 \\
11 & 3.0 & 9.0 & 24 & 15.0 & 5.0 \\
12 & 3.0 & 17.0 & 25 & 15.0 & 9.0 \\
13 & 22.0 & 14.0 & & & \\
\hline
\end{tabular}

Table 6. Prediction set for constructing PLS and PCR methods in determination of $\mathrm{Ce}^{4+}$ and $\mathrm{Cr}_{2} \mathrm{O}_{7}{ }^{2-}$.

\begin{tabular}{|c|c|c|c|c|c|c|}
\hline \multirow{3}{*}{ Solution } & \multirow{2}{*}{\multicolumn{2}{|c|}{$\begin{array}{l}\text { Synthetic } \\
(\mu \mathrm{g} / \mathrm{mL})\end{array}$}} & \multicolumn{4}{|c|}{ Predicted $(\mu \mathrm{g} / \mathrm{mL})$} \\
\hline & & & \multicolumn{2}{|c|}{$\mathrm{PLS}^{\mathrm{a}}$} & \multicolumn{2}{|c|}{$\mathrm{PCR}^{\mathrm{a}}$} \\
\hline & $\mathrm{Ce}^{4+}$ & $\mathrm{Cr}_{2} \mathrm{O}_{7}^{2-}$ & $\mathrm{Ce}^{4+}$ & $\mathrm{Cr}_{2} \mathrm{O}_{7}^{2-}$ & $\mathrm{Ce}^{4+}$ & $\mathrm{Cr}_{2} \mathrm{O}_{7}^{2-}$ \\
\hline 1 & 13.0 & 15.0 & $13.40(103.0)$ & $15.80(105.3)$ & $13.70(105.3)$ & $15.60(104.0)$ \\
\hline 2 & 3.0 & 13.0 & $2.80(93.3)$ & $13.40(103.0)$ & $2.78(92.6)$ & $13.00(100.0)$ \\
\hline 3 & 5.0 & 10.0 & $5.10(102.0)$ & $10.20(102.0)$ & $4.80(96.0)$ & $9.90(99.0)$ \\
\hline 4 & 13.0 & 18.0 & $13.50(103.8)$ & $18.50(102.7)$ & $13.50(103.8)$ & $17.80(98.8)$ \\
\hline 5 & 13.0 & 16.0 & $12.50(96.1)$ & $15.40(96.2)$ & $12.60(96.9)$ & $15.30(95.6)$ \\
\hline 6 & 22.0 & 16.0 & $22.30(101.3)$ & $15.70(98.1)$ & $22.60(102.7)$ & $15.40(96.3)$ \\
\hline 7 & 10.0 & 13.0 & $9.60(96.0)$ & $12.70(97.7)$ & $9.80(98.0)$ & $13.10(100.7)$ \\
\hline 8 & 3.0 & 5.0 & $3.20(106.6)$ & $5.30(106.0)$ & $3.10(103.3)$ & $4.90(98.0)$ \\
\hline $\begin{array}{l}\text { Mean } \\
\text { recovery }\end{array}$ & & & 100.2 & 101.3 & 99.8 & 99.1 \\
\hline RMSEP & & & 2.97 & 3.40 & 3.03 & 2.90 \\
\hline RSEP(\%) & & & 3.19 & & 2.97 & \\
\hline
\end{tabular}

${ }^{a}$ Predicted mean (recovery percent) 
calibration during the cross validation. Figure 8 shows a plot of PRESS against the number of factors for a mixture of components. To find out minimum factors, we also used the F-statistics to carry out the significant determination [33]. The optimal number of factors, for the two components, was obtained as 2 for both PCR and PLS.

For evaluating the predictive ability of a multivariate calibration model, the root mean square error of prediction (RMSEP), relative standard error of prediction (RSEP) and squares of correlation coefficient $\left(\mathrm{R}^{2}\right)$, which is an indication of the quality fit of all the date to a straight line, can be used as follows [33,37]:

$$
\begin{gathered}
R M S E P=\left(\sum_{i=1}^{N}\left(\hat{C}_{i}-C_{i}\right)^{2} / n\right)^{1 / 2} \\
\operatorname{RSEP}(\%)=\left(\sum_{i=1}^{N}\left(\hat{C}_{i}-C_{i}\right)^{2} / \sum_{i=1}^{N}\left(C_{i}\right)^{2}\right)^{1 / 2} \times 100 \\
R^{2}=\sum_{i=1}^{N}\left(\hat{C}_{i}-C^{\prime}\right)^{2} / \sum_{j=1}^{N}\left(C_{i}-C^{\prime}\right)^{2}
\end{gathered}
$$

where $\hat{C}_{i}$ represents the estimated concentration, $C_{i}$ and $\mathrm{n}$ are the actual analyte concentration and the number of samples, respectively.

Table 7 shows the values of RSEP, RMSEP and $\mathrm{R}^{2}$ for each component using PLS and PCR. It is shown that the obtained values, for the statistical parameters, are almost the same for both PLS and PCR methods.

\subsection{Interference Study}

The study of interference ions was performed by a standard mixture solution containing $10.0 \mu \mathrm{g} / \mathrm{mL}$ of each $\mathrm{Ce}^{4+}$ and $\mathrm{Cr}_{2} \mathrm{O}_{7}{ }^{2-}$ and a certain amount of foreign ions. The following excesses of ions do not interfere (i.e., caused a relative error of less than 5\%): more than a 1000 -fold (largest amount tested) amount of $\mathrm{K}^{+}, \mathrm{Zn}^{2+}, \mathrm{Cu}^{2+}, \mathrm{Bi}^{3+}$, $\mathrm{As}^{3+}, \mathrm{Cd}^{2+}, \mathrm{Mg}^{2+}, \mathrm{Be}^{2+}, \mathrm{Cl}^{-}, \mathrm{NO}_{3}{ }^{-}, \mathrm{BO}_{3}{ }^{3-}, \mathrm{C}_{2} \mathrm{O}_{4}{ }^{2-} \mathrm{a}$ 100-fold amount of $\mathrm{Mn}^{2+}, \mathrm{Ni}^{2+}, \mathrm{Co}^{2+}, \mathrm{pb}^{2+}, \mathrm{Cr}^{3+}, \mathrm{Ca}^{2+}$; 10 -fold amount of $\mathrm{SO}_{4}{ }^{2-}, \mathrm{PO}_{4}{ }^{3-}, \mathrm{Hg}^{2+}$ and a 1 -fold amount of $\mathrm{Al}^{3+}, \mathrm{Fe}^{3+}, \mathrm{Zr}^{4+}, \mathrm{Ti}^{4+}$, I . As was to be expected,
$\mathrm{Al}^{3+}, \mathrm{Fe}^{3+}, \mathrm{Zr}^{4+}, \mathrm{Ti}^{4+}$ have a interference effect because complex forming reaction of these metallic ions with fluoride ion. The interference of iodide ion was also because oxidation reaction with $\mathrm{Ce}^{4+}$ and $\mathrm{Cr}_{2} \mathrm{O}_{7}{ }^{2-}$ as oxidants.

\subsection{Application}

To evaluate the analytical applicability of the proposed methods (PCR, PLS and HPSAM), we spiked known amounts of both $\mathrm{Ce}^{4+}$ and $\mathrm{Cr}_{2} \mathrm{O}_{7}{ }^{2-}$ into some water samples. The proposed methods were applied to determine analytes simultaneously and satisfactory results were obtained. The results are given in Table 8. The results show that the proposed methods could accurately determine the concentration of these oxidants mixture under investigation in real water samples, and there is no significant difference between the results of PCR, PLS and HPSAM for their simultaneous determination.

Table 7. Statistical parameters calculated for the prediction set using PLS and PCR models.

\begin{tabular}{lccccrl}
\hline & \multicolumn{2}{c}{ RSEP (\%) } & \multicolumn{2}{c}{ RMSEP } & \multicolumn{2}{c}{$\mathrm{R}^{2}$} \\
\hline Component & PLS & PCR & PLS & PCR & PLS & PCR \\
$\mathrm{Ce}^{4+}$ & 2.97 & 3.03 & 0.35 & 0.36 & 0.9980 & 0.9990 \\
$\mathrm{Cr}_{2} \mathrm{O}_{7}^{2-}$ & 3.40 & 2.90 & 0.64 & 0.40 & 0.9993 & 0.9988 \\
\hline
\end{tabular}

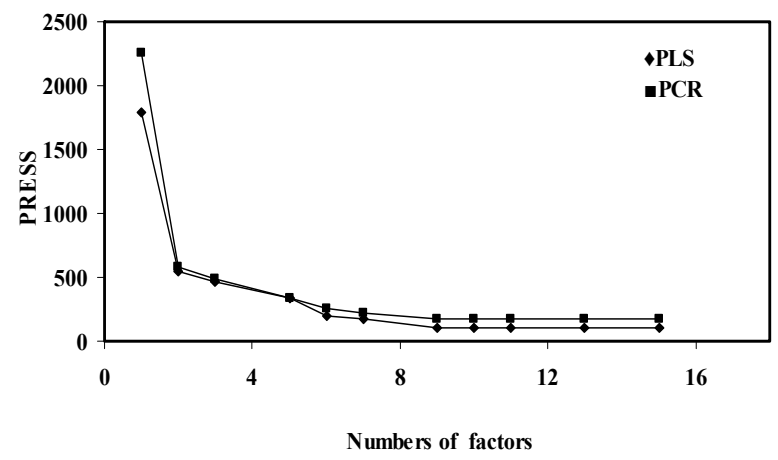

Figure 8. Plot of PRESS against the numbers of factors

\begin{tabular}{|c|c|c|c|c|c|c|c|c|}
\hline \multirow{3}{*}{ Sample } & \multirow{2}{*}{\multicolumn{2}{|c|}{ Spiked $(\mu \mathrm{g} / \mathrm{mL})$}} & \multicolumn{6}{|c|}{ Found $(\mu \mathrm{g} / \mathrm{mL})$} \\
\hline & & & \multicolumn{2}{|c|}{ HPSAM } & \multicolumn{2}{|c|}{ PLS } & \multicolumn{2}{|c|}{ PCR } \\
\hline & $\mathrm{Ce}^{4+}$ & $\mathrm{Cr}_{2} \mathrm{O}_{7}^{2-}$ & $\mathrm{Ce}^{4+}$ & $\mathrm{Cr}_{2} \mathrm{O}_{7}^{2-}$ & $\mathrm{Ce}^{4+}$ & $\mathrm{Cr}_{2} \mathrm{O}_{7}^{2-}$ & $\mathrm{Ce}^{4+}$ & $\mathrm{Cr}_{2} \mathrm{O}_{7}{ }^{2-}$ \\
\hline \multirow[t]{2}{*}{1} & 4.0 & 0.5 & $4.20 \pm 0.12$ & $0.51 \pm 0.10$ & $4.10 \pm 0.11$ & $0.46 \pm 0.05$ & $3.97 \pm 0.20$ & $0.48 \pm 0.02$ \\
\hline & 10.0 & 10.0 & $10.20 \pm 0.24$ & $10.40 \pm 0.30$ & $10.10 \pm 0.22$ & $9.88 \pm 0.20$ & $9.79 \pm 0.14$ & $9.90 \pm 0.10$ \\
\hline 2 & 3.0 & 15.0 & $2.90 \pm 0.06$ & $15.40 \pm 0.25$ & $2.97 \pm 0.05$ & $14.80 \pm 0.28$ & $3.10 \pm 0.10$ & $15.20 \pm 0.20$ \\
\hline \multirow[t]{2}{*}{3} & 25.0 & 4.0 & $24.60 \pm 0.36$ & $4.10 \pm 0.10$ & $24.8 \pm 0.33$ & $3.88 \pm 0.09$ & $25.4 \pm 0.28$ & $4.16 \pm 0.15$ \\
\hline & 18.0 & 20.0 & $17.80 \pm 0.28$ & $19.30 \pm 0.20$ & $17.65 \pm 0.37$ & $19.10 \pm 0.12$ & $18.20 \pm 0.13$ & $19.8 \pm 0.21$ \\
\hline
\end{tabular}
$\operatorname{PLS}(\diamond)$ and PCR(ם).

Table 8. Simultaneous determination of $\mathrm{Ce}^{4+}$ and $\mathrm{Cr}_{2} \mathrm{O}_{7}{ }^{2-}$ in different water samples using HPSAM, PCR and PLS methods. 


\section{Conclusions}

This work as the first application of PCR, PLS and HPSAM in the simultaneous determination of the binary mixture of $\mathrm{Ce}^{4+}$ and $\mathrm{Cr}_{2} \mathrm{O}_{7}^{2-}$ shows the ability and excellent performance of ISEs as detectors not only for individually determination of produced or consumed ions, but also in the simultaneous kinetic-potentiometric analysis. In addition, this paper has also demonstrated that the ability and advantages of the HPSAM and chemometrics methods such as PCR and PLS, ISEs and kinetic methods produce a very attractive and excellent technique for the analysis of multi-component oxidant mixtures. Other chemometrics approaches like ANN, ISEs (flouride, bromide, iodide, etc) and other kinetic reactions in which the rate of production or consumption of the corresponding ion is different can also be used. Our team has obtained good results for the simultaneous determination of other species using HPSAM, chemometrics methods, different ISEs and various reaction systems and our complete results will be presented for publication in the future.

\section{Acknowledgements}

The authors would like to express their appreciations to Professor Afsaneh Safavi and Professor Hamid Abdollahi for their valuable discussion and useful suggestions. This research was supported by the Payame Noor Universities of Ardakan and Sirjan.

\section{References}

[1] K. Basavaiah and B. C. Somashekar, "Quantitation of Ranitidine in Pharmaceuticals by Titrimetry and Spectrophotometry Using Potassium Dichromate as the Oxidimetric Reagent," Journal of the Iranian Chemical Society, Vol. 4, No. 1, 2007, pp. 78-88.

[2] O. Z. Zhai, "Catalytic Kinetic Spectrophotometric Determination of Trace Amounts of Ethylenediaminetetraacetic Acid Based on its Catalytic Effect on the Reaction of Rhodamine B and Potassium Dichromate," Instrumentation Science and Technology, Vol. 29, No. 38, 2010, pp. 72-82.

[3] J. C. Dacons, H. G. Adolph and M. J. Kamlet, "Selective Solvent-Free Oxidation of Alcohols with Potassium Dichromate," Tetrahedron Letters, Vol. 43, No. 49, 2002, pp. 8843-8844.

[4] J. Sumaoka, W. Chen, Y. Kitamura, T. Tomita, J. Yoshida and M. Komiyama, "Application of Cerium(IV)/ EDTA Complex for Future Biotechnology," Journal of Alloys and Compounds, Vol. 408-412, 2006, pp. 391-395.

[5] I. D. Nickson, C. Boxall, A. Jackson and G. O. H. Whillock, "A Spectrophotometric Study of Cerium IV and Chromium VI Species in Nuclear Fuel Reprocessing Process Streams," IOP Conference Series: Materials
Science and Engineering, Vol. 9, No. 1, 2010.

[6] H. J. Vieira and O. Fatibello-Filho, "Indirect Flow Injection Determination of N-acetyl-L-cysteine Using Cerium (IV) and Ferroin," Química Nova, Vol. 28, No. 5, 2005, pp. 797-800.

[7] Y. Liu and P. Wang, "Kinetic Spectrophotometric Method for the Determination of Cerium(IV) with Naphthol Green B," Rare Metals, Vol. 28, No. 1, 2009, pp. 5-8.

[8] A. M. Stoyanova, "Catalytic Spectrophotometric Determination of Chromium", Turkish Journal of Chemistry, Vol. 29, No. 4, 2005, pp. 367-375.

[9] M. M. Karim, S. H. Lee, Y. S. Kim, H. S. Bae and S. B. Hong, "Fluorimetric Determination of Cerium(IV) with Ascorbic Acid," Journal of Fluorescence, Vol. 16, No. 1, 2006, pp. 17-22.

[10] M. Mazloum-Ardakani, M. Salavati-Niasari, A. Dastanpour, "Determination of Chromate and Dichromate by Highly Selective Coated-Wire Electrode Based on Bis (Acetylacetonato)Copper(II)," Bulletin of Electrochemistry, Vol. 20, No. 5, 2004, pp. 193-197.

[11] H. Rajantie and D. E. Williams, "Electrochemical Titration of Thiosulfate, Sulfite, Dichromate and Permanganate Using Dual Microband Electrodes," Analyst, Vol 126, No. 1, 2001, pp. 86-90.

[12] V. Mašín and J. Doležal, "Simultaneous Determination of $\mathrm{Ce}^{4+}, \mathrm{MnO}_{4}{ }^{-}$and $\mathrm{Cr}_{2} \mathrm{O}_{7}{ }^{2-}$ without Separation," Fresenius' Journal of Analytical Chemistry, Vol. 301, No. 1, 1980, p. 25.

[13] E. Shams, H. Abdollahi, M. Yekehtaz and R. Hajian, "H-Point Standard Addition Method in the Analysis by Differential Pulse Anodic Stripping Voltammetry. Simultaneous Determination of Lead and Tin," Talanta, Vol. 63, No. 2, 2004, pp. 359-364.

[14] E. Shams, H. Abdollahi and R. Hajian, "Simultaneous Determination of Copper and Bismuth by Anodic Stripping Voltammetry Using H-Point Standard Addition Method with Simultaneous Addition of Analytes," Electroanalysis, Vol. 17, No. 17, 2005, pp. 1589-1594.

[15] K. Zarei, M. Atabati and M. Karami, "H-Point Standard Addition Method Applied to Simultaneous Kinetic Determination of Antimony(III) and Antimony(V) by Adsorptive Linear Sweep Voltammetry," Journal of Hazardous Materials, Vol. 179, No. 1-3, 2010, pp. 840-844.

[16] F. Ahmadi and F. Bakhshandeh-Saraskanrood, "Simultaneous Determination of Ultra Trace of Uranium and Cadmium by Adsorptive Cathodic Stripping Voltammetry Using H-Point Standard Addition Method," Electroanalysis, Vol. 22, No. 11, 2010, pp. 1207-1216.

[17] J. Mortensen, A. Legin, A. Ipatov, A. Rudnitskaya, Y. Vlasov and K. Hjuler, "A Flow-Injection System Based on Chalcogenide Glass Sensors for Determination of Heavy Metals," Analytica Chimica Acta, Vol. 403, No. 1-2, 2000, pp. 273-277.

[18] M. Slama, C. Zaborosch, D. Wienke and F. Spener, "Chemometrical Studies on Mixture Analysis with a Single Dynamic Microbial Sensor," Sensors and Actuators B: Chemical, Vol. 44, No. 1-3, 1997, pp. 286-290. 
[19] N. Garcia-Villar, J. Saurina and S. Hernández-Cassou, "Flow Injection Differential Potentiometric Determination of Lysine by Using a Lysine Biosensor," Analytica Chimica Acta, Vol. 477, No. 2, 2003, pp. 315-324.

[20] M. Akhond, J. Tashkhourian and B. Hemmateenejad, "Simultaneous Determination of Ascorbic, Citric and Tartaric Acids by Potentiometric Titration with PLS Calibration," Journal of Analytical Chemistry, Vol. 61, No. 8, 2006, pp. 804-808.

[21] Y. Z. Ye and Y. Luo, "Kinetic Potentiometry Simultaneous Determination of Iron(III) and Zirconium(IV) by Using the Kalman Filter," Laboratory Robotics and Automation, Vol. 10, No. 5, 1998, pp. 283-287.

[22] M. A. Karimi, M. Mazloum-Ardakani, H. Abdollahi and F. Banifatemeh, "Application of H-Point Standard Addition Method and Partial Least Squares to the Simultaneous Kinetic-Potentiometric Determination of Hydrazine and Phenylhydrazine," Analytical Science, Vol. 24, No. 2, 2008, pp. 261-266.

[23] M. A. Karimi, H. Abdollahi, H. Karami and F. Banifatemeh, "Simultaneous Kinetic-Potentiometric Determination of Hydrazine and Thiosemicarbazide by Partial Least Squares and Principle Component Regression Methods," Journal of the Chinese Chemical Society, Vol. 55, No. 1, 2008, pp. 129-136.

[24] M. A. Karimi, M. H. Mashhadizadeh, M. MazloumArdakani and N. Sahraei, "Simultaneous Kinetic-Potentiometric Determination of Levedopa and Carbidopa Using Multivariate Calibration Methods", Journal of Food and Drug Analysis, Vol. 16, No. 5, 2008, pp. 39-47.

[25] M. A. Karimi, M. Mazloum Ardakani, R. Behjatmanesh Ardakani and M. R. Zand Monfared, "Simultaneous Kinetic-Potentiometric Determination of $\mathrm{Fe}^{3+}$ and $\mathrm{Al}^{3+}$ Using H-point Standard Addition and Partial Least Squares Methods," Chemical Analysis (Warsaw), Vol. 54, No. 6, 2009, pp. 1321-1337.

[26] M. A. Karimi, M. Mazloum-Ardakani, R. Behjatmanes Ardakani, M. H. Mashhadizadeh, M. R. Zand Monfared and M. Tadayon, "Chemometrics-Assisted Kinetic-Potentiometric Methods for Simultaneous Determination of $\mathrm{Fe}(\mathrm{III}), \mathrm{Al}(\mathrm{III})$, and $\mathrm{Zr}(\mathrm{IV})$ Using a Fluoride Ion-Selective Electrode," Journal of AOAC International, Vol. 93, No. 1, 2010, p. 327

[27] E. Athanasiou-Malaki, M. A. Koupparis and T.P. Hadjiioannou, "Kinetic-Potentiometric Study and Analytical Applications of Micellar-Catalysed Reactions of 1- Fluoro2,4-Dinitrobenzene with Amino Compounds," Analytica Chimica Acta, Vol. 219, No. 2, 1989, pp. 295-307.

[28] K. Srinivasan and G. A. Rechnitz, "Activity Measurements with a Fluoride-Selective Membrane Electrode," Analytical Chemistry, Vol. 40, No. 3, 1968, pp. 509-512.
[29] F. Bosch-Reig, P. Campins-Falco, A. Sevillano-Cabeza, R. Herraez-Hernandez and C. Molins-Legua, "Development of the H-Point Standard Additions Method for Ultraviolet-Visible Spectroscopic Kinetic Analysis of TwoComponent Systems," Analytical Chemistry, Vol. 63, No. 21, 1991, pp. 2424-2429.

[30] M. Bahram, K. Farhadi, A. Afkhami, D. Shokatynia and F. Arjmand, "Simultaneous Kinetic Spectrophotometric Determination of $\mathrm{Cu}(\mathrm{II}), \mathrm{Co}(\mathrm{II})$ and $\mathrm{Ni}(\mathrm{II})$ Using Partial Least Squares (PLS) Regression," Central European Journal of Chemistry, Vol. 7, No. 3, 2009, pp. 375-381.

[31] M.A. Karimi, M. Mazloum-Ardakani, R. BehjatmaneshArdakani, M. H. Mashhadizadeh and N. Zarea Zadeh, "Application of H-Point Standard Addition Method and Multivariate Calibration Methods to the Simultaneous Kinetic-Potentiometric Determination of Hydrogen Peroxide and Peracetic Acid," Analytical \& Bioanalytical Electrochemistry, Vol. 1, No. 3, 2009, pp. 142-158.

[32] M. Chamsaz, A. Safavi and J. Fadaee, "Simultaneous Kinetic-Spectrophotometric Determination of Carbidopa, Levodopa and Methyldopa in the Presence of Citrate with the Aid of Multivariate Calibration and Artificial Neural Networks," Analytica Chimica Acta, Vol. 603, No. 2, 2007, pp. 140-146.

[33] M. Otto and W. Wegscheider, "Spectrophotometric Multicomponent Analysis Applied to Trace Metal," Analytical Chemistry, Vol. 57, No. 1, 1985, pp. 63-69.

[34] M. A. Karimi, M. Mazloum-Ardakani, R. BehjatmanehArdakani, M. R. Hormozi Nezhad and H. Amiryan, "Individual and Simultaneous Determinations of Phenothiazine Drugs Using PCR, PLS and (OSC)-PLS Multivariate Calibration Methods," Journal of the Serbian Chemical Society, Vol. 72, No. 2, 2008, pp. 233-247.

[35] M. A. Karimi, M. Mazloum-Ardakani, O. Moradlou, R. Behjatmanesh-Ardakani and F. Banifatemeh, "Simultaneous Kinetic-Spectrophotometric Determination of Hydrazine and its Derivatives by Partial Least Squares and Principle Component Regression Methods," Journal of the Chinese Chemical Society, Vol. 54, No. 1, 2007, pp. 15-21.

[36] D. M. Haaland and E. V. Thomas, "Partial Least-Squares Methods for Spectral Analyses. 1. Relation to other Quantitative Calibration Methods and the Extraction of Qualitative Information," Analytical Chemistry, Vol. 60, No. 11, 1988, pp. 1193-1202.

[37] M. A. Karimi, M. Mazloum-Ardakani, M. H. Mashhadizadeh and F. Banifatemeh, "Simultaneous Kinetic Spectrophotometric Determination of Hydrazine and Isoniazid Using H-Point Standard Addition Method and Partial Least Squares Regression in Micellar Media," Croatica Chemica Acta, Vol. 84, No. 4, 2009, pp. 729-738. 